\title{
PELAKSANAAN FUNGSI PELAYANAN OMBUDSMAN NUSA TENGGARA TIMUR DALAM MEWUJUDKAN PELAYANAN PUBLIK YANG PRIMA
}

\author{
Kevy Listiana Fransiska Taneo \\ Program Studi Magister Ilmu Hukum Universitas Nusa Cendana Kupang \\ NTT, Indonesia \\ Email : kevylistianataneo@gmail.com \\ Yohanes G.Tubahelan \\ Program Studi Magister Ilmu Hukum Universitas Nusa Cendana Kupang \\ NTT, Indonesia \\ Email : tubahelanjohn@gmail.com \\ Kotan Y. Stefanus \\ Program Studi Magister Ilmu Hukum Universitas Nusa Cendana Kupang \\ NTT, Indonesia \\ Email : stefanuskotan77@gmail.com
}

\begin{abstract}
Abstrak
Pelayanan pengaduan di Ombudsman NTT mengikuti standar pelayanan yang disusun mengacu pada UU 37 tahun 2008 tentang Ombudsman RI, UU NO 25 tahun 2009 tentang pelayanan publik. Khusus untuk penanganan pengaduan Ombudsman NTT membuat peraturan internal yang dikenal dengan nama Peraturan Ombudsman (PO) NO. 27 Tahun 2017 tentang penanganan pengaduan. Peran ini diwujudkan dalam hirarki kewenangan. Kewenangan yang ada tersebut merupakan kekuasaan legitimasi; Faktor Sosial, Faktor sosial yang mempengaruhi kinerja Ombudsman adalah masih rendahnya kesadaran masyarakat untuk menyampaikan laporan tentang tindakan mal administrasi. Hal ini dikarenakan masih rendahnya pengetahuan masyarakat atas tugas dan fungsi Ombudsman Republik Indonesia Perwakilan Provinsi NTT.
\end{abstract}

Kata Kunci: Faktor Sosial; Hambatan; Kepemimpinan; Ombudsman; Pelayanan; Sumber Daya Manusia.

\begin{abstract}
Complaints services in the NTT Ombudsman follow the service standards prepared referring to Law 37 of 2008 concerning the Indonesian Ombudsman, Law NO 25 of 2009 concerning public services. Specifically for handling complaints, the NTT Ombudsman makes internal regulations known as the Ombudsman Regulation (PO) NO. 27 of 2017 concerning handling complaints. This role is manifested in the hierarchy of authority. The existing authority is the power of legitimacy; Social Factors, Social factors that influence the performance of the Ombudsman is the low awareness of the public to submit reports on the actions of mal administration. This is due to the low level of public knowledge of the duties and functions of the Ombudsman of the Republic of Indonesia, the Representative of the NTT Province.
\end{abstract}

Keywords: Social Factors; Obstacles; Leadership; Ombudsman; Service; Human Resources. 


\section{A. PENDAHULUAN}

Reformasi bertujuan menata kembali perikehidupan berbangsa dan bernegara, pemerintah telah melakukan perubahan-perubahan mendasar dalam sistem ketatanegaraan dan sistem pemerintah Republik Indonesia. Perubahan dimaksud dilakukan antara lain dengan membentuk lembaga-lembaga negara dan lembaga-lembaga pemerintah baru. Salah satu di antaranya adalah Ombudsman Nasional Indonesia. Lembaga ini dibentuk pada tanggal 10 Maret 2000, dengan Keputusan Presiden Nomor 44 tahun 2000 tentang Komisi Ombudsman Nasional. Pembentukan Komisi Ombudsman Nasional (Ombudsman) di Indonesia dilatarbelakangi oleh suasana transisi menuju demokrasi. Pada saat itulah Gus Dur sebagai Presiden RI memutuskan membentuk Ombudsman sebagai lembaga yang diberi wewenang mengawasi kinerja pemerintahan (termasuk dirinya sendiri) dan pelayanan umum lembaga peradilan. ${ }^{1}$

Ombudsman adalah lembaga negara yang mempunyai kewenangan mengawasi penyelenggaraan pelayanan publik, baik yang diselenggarakan penyelenggara negara maupun pemerintah, Termasuk memiliki kewenangan dalam mengawasi pelayanan publik yang diselenggarakan badan usaha milik negara, badan usaha milik daerah, badan hukum milik negara, serta badan swasta atau perseorangan yang diberi tugas menyelenggarakan pelayanan publik tertentu, yang sebagian atau seluruh dananya bersumber dari Anggaran Pendapatan dan Belanja Negara dan atau Anggaran Pendapatan dan Belanja Daerah. Ombudsman bersifat independen dalam menjalankan tugas dan wewenangnya yang mengandung azas kebenaran, keadilan, non diskriminasi, tidak memihak, transparansi, keseimbangan dan kerahasiaan. ${ }^{2}$

Salah satu yang hakiki dari lembaga Ombudsman adalah kedudukannya sebagai lembaga pengawasan terhadap otorita public (pemerintah), dalam kedudukannya tersebut lembaga Ombudsman berfungsi menerima pengaduan dari masyarakat atas sikap tindak pemerintahan yang melanggar hukum, hak asasi manusia ataupun nilai-nilai kepatutan yang berkembang di dalam kehidupan masyarakat. Bagaimanapun Ombudsman sebagai institusi pengawasan tetap berjalan di tempatnya agar penyelenggara negara yang memperoleh dorongan Ombudsman segera berjalan cepat menuju ke arah pemerintahan yang lebih baik (good government).

Upaya lembaga ombudsman di Indonesia oleh pemerintah dimulai ketika presiden B.J. Habibie berkuasa, kemudian dilanjutkan oleh penggantinya, yakni K.H. Abdurahman Wahid. Masa pemerintahan K.H. Abdurahman Wahid disebut sebagai tonggak sejarah pembentukan lembaga Ombudsman, sedangkan pada masa pemerintah B.J. Habibie dapat disebut sebagai masa perintisan dalam pembentukan lembaga Ombudsman di Indonesia. ${ }^{3}$ Lengsernya Soeharto dari kursi kepresidenan pada tahun 1998 menyebabkan keinginan untuk membentuk lembaga Ombudsman seolah-olah mendapatkan momentum. Pemerintah pada waktu itu tampak sadar akan perlunya lembaga Ombudsman di Indonesia menyusul adanya tuntutan masyarakat yang amat kuat untuk mewujudkan pemerintah yang bersih dan penyelenggaraan Negara yang baik atau clean government dan good governance.

Setelah Presiden B.J. Habibie lengser, pemerintahan dilanjutkan Gus Dur dan Megawati Soekarno Putri saat itu harus menanggung politik dan sejarah masa lalu yang cukup berat. Korupsi tetap merajalela dan bahkan cenderung tanpa kendali. Penegak hukumjuga mewujudkan cita-cita reformasi hukum yakni hukum yang menjadi salah satu agenda reformasi. Masyarakat dan mahasiswa kembali melontarkan kritik atas ketidakmampuan pemerintah memberantas korupsi dan berbagai penyimpangan yang dilakukan penyelenggara Negara. Pemerintah juga semakin kehilangan kewibawaan karena terus-menerus terlibat polemik kontroversial sehingga tidak sempat mengurusi kebutuhan dasar masyarakatnya.

${ }^{1}$ Budhi Masthuri. (2005). Menegenal Ombudsman Indonesia. Jakarta:Pradnya Pramita.hlm.8

${ }^{2}$ Ombudsman Indonesia. (2002). Masa Lalu, Sekarang dan Masa Mendatang. Jakarta:Komisi Ombudsman Nasional

${ }^{3}$ Galang Asmara. (2005). Ombudsman Nasional dalam Sistem Pemerintahan Negara Republik Indonesia. Yogyakarta:Laksbang Presindo. hlm. 15.

310 Kevy Taneo, Yohanes Tubahelan \& Kotan Stefanus | Pelaksanaan Fungsi.... 
Lebih lanjut dalam kondisi mendapat tekanan masyarakat yang menghedaki terjadinya perubahan menuju pemerintah yang transparan, bersih dan bebas korupsi, kolusi dan nepotisme, maka saat itu pemerintah berusaha melakukan beberapa perubahan sesuai aspirasi yang berkembang di tengah masyarakat. Salah satunya adalah dengan memebentuk sebuah lembaga pengawasan terhadap penyelenggara Negara, yang bernama Komisi Ombudsman Republik Indonesia. Demikianlah maka sejak ditetapkannya Keputusan Presiden pada tanggal 10 Maret tahun 2000 berdirilah lembaga Ombudsman Republik Indonesia dengan nama Komisi Ombudsman Nasional.

Menurut Kepres No. 44 Tahun 2000, pembentukan lembaga ombudsman di Indonesia dilatarbelakangi oleh tiga pemikiran dasar sebagaimana tertuang di dalam konsiderannya, yakni : (1) Bahwa pemberdayaan masyarakat melalui peran serta mereka melakukan pengawasan akan lebih menjamin penyelenggaraan Negara yang jujur, bersih, transparan, bebas korupsi, kolusi, dan nepotisme; (2) Bahwa pemberdayaan pengawasan oleh masyarakat terhadap penyelengaaran Negara merupakan implementasi demokrasi yang perlu dikembangkan serta diaplikasikan agar penyalahgunaan kekuasaan wewenang ataupun jabatan oleh aparatur dapat diminimalisasi; dan (3) Bahwa dalam penyelenggaraan Negara khususnya penyelenggaraan pemerintahan memberikan pelayanan dan perlindungan terhadap hak-hak anggota masyarakat oleh aparatur pemerintah termasuk lembaga peradilan merupakan bagian yang tidak terpisahkan dari upaya untuk menciptakan keadilan dan kesejahteraan. ${ }^{4}$

Kemudian untuk lebih mengoptimalkan fungsi, tugas, dan wewenang Komisi Ombudsman Nasional, perlu dibentuk Undang-Undang tentang Ombudsman Republik Indonesia sebagai landasan hukum yang jelas dan kuat. Hal ini sesuai dengan amanat Ketetapan Majelis Permusyawaratan Rakyat tentang rekomendasi arah kebijakan pemberantasan dan pencegahan korupsi, kolusi, dan nepotisme yang salah satu nya memerintahkan dibentuknya Ombudsman dengan undang-undang. ${ }^{5}$ Akhirnya keinginan untuk mempunyai undang-undang tersebut terwujud pada tanggal 7 Oktober 2008 yaitu terbentuknya Undang-Undang Republik Indonesia Nomor 37 Tahun 2008 tentang Ombudsman Republik Indonesia. Pengaturan ombudsman dalam Undang-undang tidak hanya mengandung konsekuensi posisi politik kelembagaan, namun juga perluasan kewenangan dan cakupan kerja ombudsman yang akan sampai di daerahdaerah. Dalam undang-undang ini dimungkinkan mendirikan kantor perwakilan ombudsman di daerah Provinsi dan Kabupaten/Kota.

Pembentukan lembaga ombudsman bertujuan untuk membantu menciptakan dan atau mengembangkan kondisi yang kondusif dalam melaksanakan pemberantasan Korupsi, Kolusi, dan Nepotisme (KKN) melalui peranserta masyarakat. Selain itu, dalam keputusan Presiden Nomor 44 tahun 2000 dinyatakan pula bahwa pembentukan Ombudsman Republik Indonesia sebagai upaya untuk meningkatkan perlindungan hak-hak masyarakat agar memperoleh pelayanan umum, keadilan dan kesejahteraan secara lebih baik. Dengan demikian, maka keberadaan lembaga Ombudsman Republik Indonesia tersebut dalam sistem ketatanegaraan dan system pemerintah Negara Republik Indonesia adalah sebagai lembaga pengawasan sekaligus juga sebagai lembaga perlindungan hukum bagi rakyat di Indonesia.

Lebih lanjut, dalam undang-undang tersebut Ombudsman Republik Indonesia diberi kewenangan mengawasi pemberian pelayanan umum oleh penyelenggara Negara dan pemerintah kepada masyarakat. Penyelenggara Negara dimaksud meliputi lembaga peradilan, kejaksaan, kepolisian, badan pertanahan nasional, pemerintah daerah, instansi departeman dan nondepartemen, BUMN, dan perguruan tinggi negeri serta badan swasta dan perorangan yang seluruh /sebagian anggaranya menggunakan APBN/APBD. Ombudsman Republik

\footnotetext{
${ }^{4}$ Keputusan Presiden Nomor 44 Tahun 2000 Tentang Komisi Ombudsman Nasional

${ }^{5}$ Penjelasan Undang-Undang Negara Republik Indonesia No. 37 Tahun 2008 Tentang Ombudsman Republik Indonesia
} 
Indonesia yang merupakan lembaga Negara bersifat mandiri dan tidak memiliki hubungan organik dengan lembaga Negara dan instansi pemerintahan lainnya, serta dalam menjalankan tugas dan wewenangnya bebas dari campur tangan kekuasaan lainnya.

Hasil studi awal yang dilakukan penulis di kantor Ombudsman Provinsi NTT yang berkaitan dengan jumlah kasus yang ditangani oleh Ombudsman perwakilan NTT dalam rentang waktu 3 tahun terakhir (2016-2018). Kasus yang telah ditangani dalam kurun waktu 3 tahun terakhir ini sebanyak 1508 kasus dimana 1.322 kasus telah selesai ditangani (berstatus "kasus ditutup") sedangkan sisanya masing dalam proses penanganan. Kasus-kasus yang ditangani ini berkaitan dengan persoalan pelayanan publik dari berbagai instansi yang dilaporkan oleh masyarakat maupun inisiatif investigasi.

Selain itu dari total 1508 kasus tersebut tersebar diberbagai wilayah dalam provinsi NTT. Kasus yang ditangani pada tahun 2016 berjumlah 565 kasus dan kasus yang berstatus "kasus ditutup" berjumlah 565 kasus, tahun 2017 sebanyak 440 kasus dan kasus yang berstatus "kasus ditutup" sebanyak 440, dan pada tahun 2018 sebanyak 317 berstatus "kasus ditutup.

Berdasarkan hasil wawancara yang dilakukan oleh penulis dengan sekretaris Ombudsman wilayah NTT mengemukakan bahwa proses penangan kasus di luar wilayah Kupang dilaksanakan melalui proses monitoring langsung ke lapangan, investigasi untuk masalah yang sudah urgen dan butuh klarifikasi secara langsung; sedangkan kasus-kasus yang tidak urgen atau hanya butuh laporan maupun klarifikasi tertulis pegawai Ombudsman tidak melakukan investigasi secara langsung; ada juga kasus yang hanya membutuhkan saran.

Melihat fenomena di atas, tentunya mempengeruhi tingkat kepercayaan masyarakat terdapat kinerja Ombudsman sebagai lembaga pelayanan publik. Hal ini didukung dari hasil wawancara yang dilakukan oleh peneliti berkaitan dengan persepsi masyakarat tentang Ombudsman ditemui berbagi fenomena diantaranya kurangnya pemahaman masyakarat tentang apa itu Ombudsman dan perannya sebagai lembaga pelayanan publik. Hal inilah yang memicu rendahnya kinerja lembaga ini dalam melaksanakan tugasnya; selain rendahnya pemahaman masyakarat tentang Ombudsman itu sendiri; tingkat kepercayaan masyarakat juga minim; yang mana masyarakat dalam pengaduannya terhadap pelayanan publik di berbagai instansi pemerintahan cenderung langsung mengadungkannya kepada instansi terkait sehingga belum terlihat peranan Ombudsman sebagai pelayanan publik.

Ombudsman selaku lembaga yang memiliki fungsi sebagai pelayanan publik memiliki peran yang sangat penting dalam menampung berbagai pengaduan masyarakat terhadap kualitas pelayanan di berbagai instansi yang ada dalam wilayah otoritas Ombudsman itu sendiri. Namun berdasarkan hasil studi awal yang telah diapaparkan di atas, terlihat rendahnya kinerja Ombudsman dalam melaksanakan fungsinya sebagai pelayanan publik yang berdampak pada kurangnya tingkat kepercayaan masyarakat kedapa lembaga ini; seperti yang telah dipaparkan salah satu faktornya adalah sedikitnya pegawai Ombudsman wilayah Nusa Tenggara Timur yang menyebabkan rendahnya kinerja dari Ombudsman NTT; selain itu berdasarkan data awal yang diperoleh dari hasil wawancara dengan beberapa tokoh masyarakat ditemukan masih sedikit masyarakat yang mengenal dan mengetahui secara jelas tentang fungsi Ombudsman selaku lembaga pelayanan publik terkhususnya masyarakat yang memiliki status ekonomi menegah ke bawah.

Kedua aspek di atas, tentunya menjadi persoalan tersendiri yang menghambat pelaksanaan fungsi pelayanan publik dari Ombudsman karena harapan dari lembaga Ombudsman sendiri adalah untuk mengatasi berbagai pengaduan yang berkaitan dengan pelayanan publik bagi masyarakat belum terpenuhi secara maksimal dan juga minimnya pemahamahan serta kepercayaan masyarakat terhadap Ombudsman; untuk itu peneliti tertarik untuk melakukan penelitian lebih mendalam tentang pelaksanaan fungsi Ombudsman dalam mewujudkan 
pelayanan publik bagi masyarakat Nusa Tenggara Timur serta faktor-faktor yang menghambat kinerja Ombudsman selaku pelayan publik. Untuk itu permasalahan penelitian ini pertama, bagaimanakah pelaksanaan fungsi pengawasan Ombudsman NTT dalam mewujudkan pelayanan publik yang prima; apa sajakah hambatan yang dialami oleh Ombudsman dalam pelaksanaan fungsi ombudsman dalam mewujudkan pelayanan publik yang prima.

\section{B. METODE PENELITIAN}

Penelitian ini menggunakan metode penelitian yuridis empiris, dalam hal ini penulis mengumpulkan data dari hasil wawancara dengan responden yang berkaitan dengan pelaksanaan fungsi Ombudsman sebagai lembaga pelayanan publik.

\section{PEMBAHASAN}

\section{Pelaksanaan Fungsi Ombudsman NTT dalam Menerima Pengaduan dan Laporan dari Masyarakat}

Mendorong penyelenggaraan negara dan pemerintahan yang efektif dan efisien, jujur, terbuka, bersih, serta bebas dari korupsi, kolusi dan nepotisme, Pasal 7 huruf a Undang-Undang Nomor 37 Tahun 2008 tentang Ombudsman RI mengatur mengenai tugas Ombudsman yaitu menerima laporan atas dugaan maladministrasi dalam penyelenggaraan pelayanan publik. Wilayah Provinsi Nusa Tenggara Timur (NTT), sejak Januari hingga Maret 2018 Ombudsman RI Perwakilan Provinsi NTT telah menerima laporan sejumlah 317. Laporan ini kemudian dibagi dalam beberapa kategori oleh Tim Penerimaan dan Verifikasi Laporan Ombudsman RI Perwakilan NTT yaitu Laporan, Konsultasi Non Laporan, Surat Tembusan, Bukan Laporan.

Lebih lanjut, dalam hal kategori Laporan, Tim Penerimaan dan Verifikasi Laporan Ombudsman RI Perwakilan NTT memeriksa syarat formil dan syarat materiil. Hasilnya kemudian akan menentukan Laporan tersebut termasuk dalam kewenangan Ombudsman atau bukan. Dari 317 akses masyarakat ke Ombudsman RI Perwakilan Provinsi NTT sampai pada bulan Maret, 133 akses merupakan Konsultasi Non Laporan, 33 akses merupakan Surat Tembusan, 21 akses bukan laporan, 5 akses merupakan laporan yang bukan merupakan kewenangan, 56 akses telah diregistrasi sebagai laporan, dan 69 akses sedang dalam proses verifikasi.

Tiga substansi terbanyak yang dilaporkan yaitu Kepolisian, Pertanahan, dan Pendidikan. Sementara instansi terbanyak yang dilaporkan adalah Pemerintah Kabupaten/Kota, Kepolisian Resort, dan BUMN/BUMD. Untuk daerah terlapor terbanyak adalah Kota Kupang, Kabupaten Kupang, dan Kabupaten Timor Tengah Selatan. Adapun sebaran dugaan maladministrasi adalah dugaan tidak memberikan pelayanan, dugaan penyimpangan prosedur, dugaan penundaan berlarut, dugaan tidak kompeten pemberi layanan, dugaan penyalahgunaan wewenang, dugaan permintaan imbalan, dan dugaan tindakan tidak patut pemberi layanan.

Ombudsman RI Perwakilan Provinsi NTT menyambut baik besarnya partisipasi masyarakat dalam rangka mengawasi pelayanan publik di lingkup Provinsi NTT. Untuk memperbanyak akses masyarakat ke Ombudsman, Ombudsman RI Perwakilan Provinsi NTT akan kembali menyebarkan pigura ombudsman ri perwakilan provinsi NTT yang memuat mekanisme melapor dan nomor telepon yang bisa dihubungi masyarakat ke beberapa pulau lain setelah sebelumnya menyebarkan Pigura tersebut ke instansi-instansi yang berada di seluruh kabupaten yang ada di Pulau Timor. Berikut ini akan dipaparkan mekanisme penyelesaian laporan oleh ombudsman:

a. Penerimaan laporan dan verifikasi laporan oleh Tim Penerimaan dan Verifikasi Laporan (Tim PVL) Ombudsman RI Perwakilan Provinsi NTT; 
b. Laporan tersebut dinyatakan lolos verifikasi formil dan materil oleh Tim PVL kemudian didiskusikan dalam rapat perwakilan untuk disetujui atau ditolak untuk dilanjutkan ke proses penyelesaian laporan;

c. Hasil rapat perwakilan, bahwa laporan disetujui untuk dilakukan pemeriksaan dan diproses untuk diselesaikan oleh Tim Penyelesaian Laporan (PL);

d. Asisten Tim PL melakukan Pemeriksaan Berkas Laporan dan menerbitkan Laporan Hasil Pemeriksaan Dokumen (LHPD) yang pada intinya menyatakan, bahwa laporan tersebut mengandung dugaan maladministrasi berupa tidak memberikan pelayanan oleh Terlapor;

e. Asisten Tim PL melakukan permintaan penjelasan/klarifikasi kepada Terlapor melalui surat dan menunggu respon Terlapor selama 14 (empat belas) hari kerja. Adapun dalam surat tersebut, termuat beberapa poin pertanyaan yang merujuk pada aturan/ dasar hukum terkait dugaan maladministrasi yang terjadi untuk dimintakan penjelasannya kepada Terlapor;

f. Asisten Tim PL menerima tanggapan dari Terlapor dalam waktu kurang dari 14 (empat belas) hari, bahwa Terlapor menjawab poin-poin pertanyaan dari Ombudsman dan akan segera menindaklanjutipengaduanPelapordenganmelayanipenandatanganan formulirpermohonan dari Kantor Pertanahan yang diajukan Pelapor;

g. Asisten Tim PL menyampaikan tanggapan Terlapor melalui surat kepada Pelapor sebagai pemberitahuan perkembangan hasil pemeriksaan oleh Ombudsman;

h. Asisten Tim PLmenerima pemberitahuan dariPelapor, bahwakeluhannya telah ditindaklanjuti oleh Terlapor dan telah mendapat penyelesaian;

i. Asisten Tim PL menyusun Laporan Akhir Hasil Pemeriksaan (LAHP) yang kemudian disampaikan kepada Pelapor dan Terlapor, dimana LAHP tersebut memuat uraian laporan, serangkaian pemeriksaan yang telah dilakukan oleh Asisten PL yang menangani laporan tersebut, dasar hukum/ aturan-aturan yang digunakan sebagai landasan pembuktian terjadinya maladministrasi serta pendapat Ombudsman terhadap Laporan Pelapor;

j. Asisten Tim PL membuat dan menetapkan Berita Acara Penutupan Laporan (BAPL).

k. Laporan Ditutup oleh Asisten Tim PL.

\section{Urgensi Masalah atau Masalah-masalah yang dominan di NTT}

Permasalahan yang masuk ke ombudsman perwakilan NTT dari tahun 2016 sampai 2017 tercatat ada tiga substansi masalah yang sangat dominan sebagaimana tercatat pada tabel di bawah ini:

\begin{tabular}{|c|c|c|c|c|c|}
\hline \multirow[t]{2}{*}{ No } & \multirow[t]{2}{*}{ Permasalahan } & \multirow[t]{2}{*}{ Subtansi laporan } & \multicolumn{2}{|c|}{ Jumlah kasus } & \multirow[t]{2}{*}{ Keterangan kasus } \\
\hline & & & 2016 & 2017 & \\
\hline 1. & Kepolisian & $\begin{array}{r}\text { Tidak memberi- } \\
\text { kan pelayanan } \\
\text { yang baik }\end{array}$ & 98 & 91 & Terselesaikan \\
\hline 2. & Agrarian/ pertanahan & $\begin{array}{l}\text { Tidak memberikan pe- } \\
\text { layanan yang baik }\end{array}$ & 67 & 45 & Terselesaikan \\
\hline 3. & $\begin{array}{r}\text { Administrasi Kepen- } \\
\text { dudukan }\end{array}$ & $\begin{array}{r}\text { Tidak memberikan pe- } \\
\text { layanan yang baik }\end{array}$ & 53 & 45 & Terselesaikan \\
\hline
\end{tabular}

Sumber Data: Data Sekunder

\section{Kepolisian}

Substansimasalahpadalembagakepolisianyangdilaporkankeombudsmanperwakilan NTT pada umunya terkait dengan tidak memberikan pelayanan dengan baik oleh lembaga kepolisian. Misalnya dalam peroses pengurusan SIM serta terkait lambannya penanganan kasus yang dilaporkan ke pihak kepolisian.

2. Agrarian/ pertanahan 
Pelayanan publik di bidang Agraria dan Tata Ruang Badan Pertanahan Nasional (BPN) berada dalam tiga besar substansi pelayanan yang di keluhkan masyarakat di seluruh Kabupaten di NTT. Substansi pelayanan yang paling banyak dikeluhkan terkait dengan peningkatan kualitas penyelenggaraan pelayanan publik di bidang agraria serta percepatan penanganan aduan masyarakat. Permasalahan penerbitan sertifikat ganda, lambatnya penerbitn sertifikat masuk dalam substansi permasalahan agrarian di NTT.

3. Administrasi Kependudukan

Substansi permasalahan administrasi kependudukan yang dilaporkan kepada ombudsman perwakilan NTT semua terkait dengan pelayanan e-KTP yang belum dicetak serta rumitnya pelayanan pindah penduduk antar kabupaten, kota dan provinsi yang memakan waktu yang lama.

\section{Hambatan yang dialami oleh Ombudsman Berkaitan dengan Fungsinya sebagai Pelayanan Publik yang Prima di NTT}

Salah satu hambatan yang masih sering dihadapi oleh ombudsman perwakilan NTT dalam menuntaskan permasalahan maladministrasi adalah masih sangat rendah partisipasi masyarakat dalam melaporkan kasus-kasus maladministrasi yang terjadi di NTT. Dalam catatan ombudsman perwakilan NTT tercatat dalam tiga tahun terakhir sejak tahun 2016 sampai dengan 2018 tercatat 1.322 kasus maladministrasi yang dilaporkan kepada ombudsman perwakilan NTT.

a. Sumber Daya Manusia

Sumber daya merupakan bagian paling penting dalam suatu pelayanan ombudsman perwakilan propinsi NTT, tidak adanya sumber daya yang memadai di dalam sistem pelayanan ombudsman perwakilan propinsi NTT akan menyebabkan banyaknya kendala yang akan dihadapi dalam mencapai tujuan pelayanan ombudsman perwakilan propinsi NTT, sumber daya yang dimaksud berupa sumber daya manusia, sarana dan prasarana yang tersedia, sertaalokasianggaranataudanayangtersediabaikdarisegikualitasmaupunsecara kuantitas. Sumber daya manusia merupakan anggota penggerakjalannya pelayanan secara keseluruhan, sedangkan sarana dan prasarana merupakan faktor pendukung bagi sumber daya manusia untuk dapat menjalankan pelayanan ombudsman perwakilan propinsi NTT. Sehingga apabila sumber daya dalam pelayanan tidak baik, dapat dikatakan pelayanan ombudsman perwakilan propinsi NTT tidak dapat berjalan sebagaimana mestinya.

b. Kepemimpinan

Kepemimpinan dalam suatu organisasi memang selalu dimulai dari sistem peranan yang formal. Peran ini diwujudkan dalam hirarki kewenangan. Kewenangan yang ada tersebut merupakan kekuasaan legitimasi. Artinya, kekuasaan yang melekat pada jabatan tersebut untuk meyakinkan bahwa individu yang berada dalam jabatan di bawahnya telah memenuhi persyaratan yang telah ditetapkan oleh peraturan yang ada. Seseorang dengan kewenanganakanmempengaruhiorang-orangyang berada dibawah hirarkinya. Seseorang yang diatas hirarkinya langsung, menurut teori pendekatan jabatan dinamakan pimpinan.

Di tubuh Pelayanan Ombudsman Republik Indonesia Perwakilan Provinsi NTT, kepemimpinantermasuksalahsatufaktoryangmempengaruhikinerjaasistenOmbudsman. Kepala Perwakilan Ombudsman Republik Indonesia Perwakilan Provinsi NTT mampu menjaga koordinasi dan integritas pelayanan ombudsman perwakilan propinsi NTT, melakukan pilihanatas salah satualternatifyang dianggap terbaik dalam rangka pemecahan suatu problema atau dengan kata lain mengambil keputusan adalah proses berfikir logis. 


\section{c. Faktor Sosial}

Faktor sosial yang mempengaruhi kinerja Ombudsman adalah masih rendahnya kesadaran masyarakat untuk menyampaikan laporan tentang tindakan mal administrasi. Hal ini dikarenakan masih rendahnya pengetahuan masyarakat atas tugas dan fungsi OmbudsmanRepublikIndonesiaPerwakilanProvinsiNTT.Halinimenjadicatatanterhadap Ombudsman Republik Indonesia Perwakilan Provinsi NTT supaya melakukan sosialisasi tentang adanya lembaga yang menangani masalah dugaan pelanggaran penyelenggaraan pelayanan publik.

\section{KESIMPULAN}

Pelayanan pengaduan di Ombudsman NTT mengikuti standar pelayanan yang disusun mengacu pada UU 37 tahun 2008 tentang Ombudsman RI, UU NO 25 tahun 2009 tentang pelayanan publik. Khusus untuk penanganan pengaduan Ombudsman NTT membuat peraturan internal yang dikenal dengan nama Peraturan Ombudsman (PO) NO. 27 Tahun 2017 tentang penanganan pengaduan. Beberapa prinsip pelayanan yang harus dijunjung oleh instansi atau lembaga penyedia pelayanan dengn memperhatikan asas pelayanan publik, yaitu: Transparansi, Akuntabilitas, Kondisional, Partisipatif, Tidak diskriminatif, Keseimbangan hak dan kewajiban. Hambatan yang sering masih sering dihadapi oleh ombudsman perwakilan NTT dalam menuntaskan permasalahan maladministrasi adalah terkait dengan beberapa faktor di bawah ini: Sumber Daya Manusia, Sumber daya merupakan bagian paling penting dalam suatu pelayanan ombudsman perwakilan propinsi NTT, tidak adanya sumber daya yang memadai di dalam sistem pelayanan ombudsman perwakilan propinsi NTT akan menyebabkan banyaknya kendala yang akan dihadapi dalam mencapai tujuan pelayanan ombudsman perwakilan propinsi NTT; Kepemimpinan, Kepemimpinan dalam suatu organisasi memang selalu dimulai dari sistem peranan yang formal. Peran ini diwujudkan dalam hirarki kewenangan. Kewenangan yang ada tersebut merupakan kekuasaan legitimasi; Faktor Sosial, Faktor sosial yang mempengaruhi kinerja Ombudsman adalah masih rendahnya kesadaran masyarakat untuk menyampaikan laporan tentang tindakan maladministrasi. Hal ini dikarenakan masih rendahnya pengetahuan masyarakat atas tugas dan fungsi Ombudsman Republik Indonesia Perwakilan Provinsi NTT.

\section{DAFTAR PUSTAKA}

\section{Buku}

Budhi Masthuri. (2005). Menegenal Ombudsman Indonesia. Jakarta:Pradnya Pramita.

Galang Asmara. (2005). Ombudsman Nasional dalam Sistem Pemerintahan Negara Republik Indonesia. Yogyakarta:Laksbang.

Ombudsman Indonesia. (2002). Masa Lalu, Sekarang dan Masa Mendatang. Jakarta:Komisi Ombudsman Nasional Presindo

\section{Peraturan Perundang-undangan}

Undang-Undang Negara Republik Indonesia No. 37 Tahun 2008 Tentang Ombudsman Republik Indonesia

Keputusan Presiden Nomor 44 Tahun 2000 Tentang Komisi Ombudsman Nasional 